\section{HIGH PRESSURE SYNTHESIS GAS FERMENTATION ;}

\section{UNIVERSITY OF ARKANSAS}

CONTRACT NO. DE-AC22-91PC91028
$\mathrm{DOE} / \mathrm{PC} / 91028--\mathrm{T} 1$

DE $92 \quad 002.82 .4$

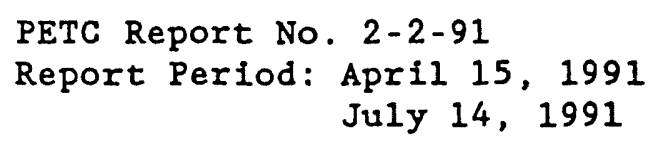

\title{
SUMMARY
}

A high pressure gas phase fermentation system is under construction. The reactors in the system consist of a $650 \mathrm{~mL}$ continuous stirred tank reactor and IL continuous column reactor. The reactors are designed for individual or dual operation in series or parallel. The system is to be housed in a constant temperature, explosion-proof room, equipped with gas leak detectors.

\section{INTRODUCTION}

Synthesis gas components $\left(\mathrm{CO}, \mathrm{H}_{2}, \mathrm{CO}_{2}\right)$ may be converted into ethanol and acetate by the anaerobic bacterium Clostridium ljungdahlii, Strain PETC, by Equations (1)-(4).

$$
\begin{aligned}
& 6 \mathrm{CO}+3 \mathrm{H}_{2} \mathrm{O} \rightarrow \mathrm{CH}_{3} \mathrm{CH}_{2} \mathrm{OH}+4 \mathrm{CO}_{2} \\
& 2 \mathrm{CO}_{2}+6 \mathrm{H}_{2} \rightarrow \mathrm{CH}_{3} \mathrm{CH}_{2} \mathrm{OH}+3 \mathrm{H}_{2} \mathrm{O} \\
& 4 \mathrm{CO}+2 \mathrm{H}_{2} \mathrm{O} \rightarrow \mathrm{CH}_{3} \mathrm{COOH}+2 \mathrm{CO}_{2} \\
& 2 \mathrm{CO}_{2}+4 \mathrm{H}_{2} \rightarrow \mathrm{CH}_{3} \mathrm{COOH}+2 \mathrm{H}_{2} \mathrm{O}
\end{aligned}
$$

Although the "wild" strain produces acetate in favor of ethanol in a $20: 1$ ratio, studies in the University of Arkansas laboratories have demonstrated that significant quantities of ethanol can be produced in favor of acetate by utilizing a poor nutrient medium, devoid of yeast extract, in combination with low operating $\mathrm{pH}$. Studies in batch culture have resulted in ethanol 
concentrations as high as $10 \mathrm{~g} / \mathrm{L}$ with no acetate production, and studies in a continuous stirred tank reactor with cell recycle have yielded ethanol concentrations as high as $6 \mathrm{~g} / \mathrm{L}$, with an ethanol to acetate product ratio greater than 100.

Synthesis gas fermentations such as this are usually mass transfer limited in continuous reaction results due to the very low gas solubilities. It has been demonstrated for other gas phase biological systems that reaction rate is proportional to pressure at least up to $10 \mathrm{~atm}$, the limit of existing experimental equipment. The retention time at 10 atm can thus be reduced to about three minutes. It is felt that retention times of only a few seconds are possible and can be demonstrated at higher pressures. With such short equivalent reaction times, the reactor volume for large scale alcohol production becomes nominal and commercial application is assured.

The purpose of this research project is to build and test a high pressure fermentation system for the production of ethanol from synthesis gas. The fermenters, pumps, controls, and analytical system will be procured or fabricated and assembled in our laboratory. This system will then be used to determine the effects of high pressure on growth and ethanol production by $\underline{C}$. ljungdahlii. The limits of cell concentration and mass transport relationships will be found in CSTR and immobilized cell reactors (ICR). The minimum retention times and reactor volumes will be found for ethanol production in these reactors. Retention times of a few seconds are expected to result from these experiments.

\section{DISCLAIMER}

This report was prepared as an account of work sponsored by an agency of the United States Government. Neither the United States Government nor any agency thereof, nor any of their employees, makes any warranty, express or implied, or assumes any legal liability or responsibility for the accuracy, completeness, or usefulness of any information, apparatus, product, or process disclosed, or represents that its use would not infringe privately owned rights. Reference herein to any specific commercial product, process, or service by trade narne, trademark, manufacturer, or otherwise does not necessarily constitute or imply its endorsement, recommendation, or favoring by the United States Government or any agency thereof. The views and opinions of authors expressed herein do not necessarily state or reflect those of the United States Government or any agency thereof. 


\section{SYSTEM CONSTRUCTION}

A schematic of the high pressure fermentation system, presently under construction, is shown in Figure 1. A synthetic synthesis gas mixture of the desired concentration will be used in the initial experimental work.

Synthesis gas from a feed gas bottle (A) will be fed through two parallel gas regulators (B), through two air-controlled shut-off valves (C) and finally metered through mass flow controllers (D) before entering the reactors. The reaction vessels will consist of both a high pressure continuous stirred tank reactor ( $O$ ) and a high pressure column reactor (P). Liquid medium necessary for the growth of the organism, will flow from a reactor fed tank (J) through pumps ( $F$ ) before entering the reactor.

$\mathrm{pH}$ control will be accomplished by monitoring the $\mathrm{pH}$ in the reactor effluent line and adjusting the $\mathrm{pH}$ in the medium feed lines. After exiting the reactor, the pressure is decreased using a pressure control valve (K). The $\mathrm{pH}$ is then measured in a combination $\mathrm{pH}$ measuring port and gas-liquid separator ( $L$ ). The $\mathrm{pH}$ is adjusted using acid and base pumps (E) in combination with base and acid reservoirs (G).

A light source is included in a recycle loop to enable the use of photosynthetic bacteria, if desired. The recycle loop consists of a pump (H) and a high pressure sight glass (N), which is used as a light exchanger.

The system is to be designed for single CSTR operation, single column reactor operation and operation of the two reactors in series or parallel. Thus, the maximum flexibility of the system is assured.

A list of the equipment, along with size and vendors, is shown in Table 1. The column reactor has been specially constructed to our specifications by the High Pressure Equipment Company, and will have working volume of $1 \mathrm{~L}$. The 
continuous stirred tank reactor will have a working volume of $650 \mathrm{~mL}$, will have air-driven agitation and will be obtained from the Parr Instrument Company. A list of vendors and their addresses is shown in Table 2.

A constant temperature, explosion-proof room has been readied for exclusive use by the high pressure fermentation system. The temperature of the room will be controlled at the desired level with an explosion-proof room heater, and gas monitors will be placed throughout the room in strategic places to ensure safety in case of leaks. The gas cylinders will be housed in an area outside the room and all non-explosion proof equipment will be separated from the rest of the system by walls or cabinets to ensure safety in case of unforseen gas leaks. A schematic of the proposed room, also under construction, is shown in Figure 2. 
Table 1

EQUIPMENT LIST

Description \& Size

Units

Feed Pump - discharge pressure of

$2500 \mathrm{psi}, 0.1-3.0 \mathrm{~mL} / \mathrm{min}$ flow rate

A. Daigger Company

Acid/Base Injection Pump - fixed

speed peristaltic pump, $0.1 \mathrm{~mL} / \mathrm{min}$

flow rate

A. Daigger Company

Recycle Pump - 1 L/min flow rate,

adjustable by using a DC motor.

System pressure 1500 psi. Pump

Head - A. Daigger Company

Motor - Evans Electric

$\mathrm{pH}$ Controller - allows for two

independent inputs, control two

relays per controller input

A. Daigger Company

Sight Glass - 2" glass diamemter, 1/4"

NPT (female) fittings rated for 1500

psi for use in recycle line.

Cyclops Industries

Gas Regulator - single stage, 1500

psi max. delivery pressure.

Matheson Gas Products

Gas Flow Controller - control mass

flow of mixture of $\mathrm{CO}, \mathrm{CO}_{2}, \mathrm{H}_{2}$, and $\mathrm{Ar}$.

Edwards High Vacuum, Inc.

Adjustable Pressure Relief Valve -

adjustable between 15-1500 psi

plus/minus 5 psi

Little Rock Valve and Fitting Company

High Pressure Filter - filters out

2

7 micron particles

Iittle Rock Valve and Ficting Company

Electrical Actuated Ball Valve -

Act as safety shut off for gas feed

Master Supply Company. 
Table 1 - continued

Air Actuated Ball Valve - act as

backup safety shut-off for gas feed

Little Rock Valve and Fitting Company

Gas Monitors - monitor for

combustible gases

Lab Safety Supply

Column Reactor - 1 I reactor

High Pressure Equipment Company

Stirred-Tank Reactor - $750 \mathrm{~mL}$ bench

top reactor with variable speed

air driven motor

Parr Instrument Company

Feed and Product Resevoirs -

Glass - 1-L 
Table 2

VENDOR LIST

A. Daigger and Company, Inc.

Daigger Scientific Division

441 Carpenter Street

Wheeling, Il 60090

Master Supply Company

708 Morris Avenue

Springdale, AR 72764

Cole-Parmer Instrument Company

7425 N. Oak Park Avenue

Chicago, IL 60648

Little Rock Valve and Fitting Company

110 Brookswood Road

North Little Rock, AR 72116

Matheson Gas Products

1921 S. Southland Avenue

Gonzales, LA 70737

Cyclops Industries, Inc.

P. O. Box 8614

432 3rd Avenue

South Charleston, WV 25303

Lab Safety Supply

P. O. Box 1368

Janesville, WI 53547-1368

High Pressure Equipment Company

1222 Linden

Erie, PA 16505

Evans Electric

P. 0. Box 147

Rogers, AR 72757 


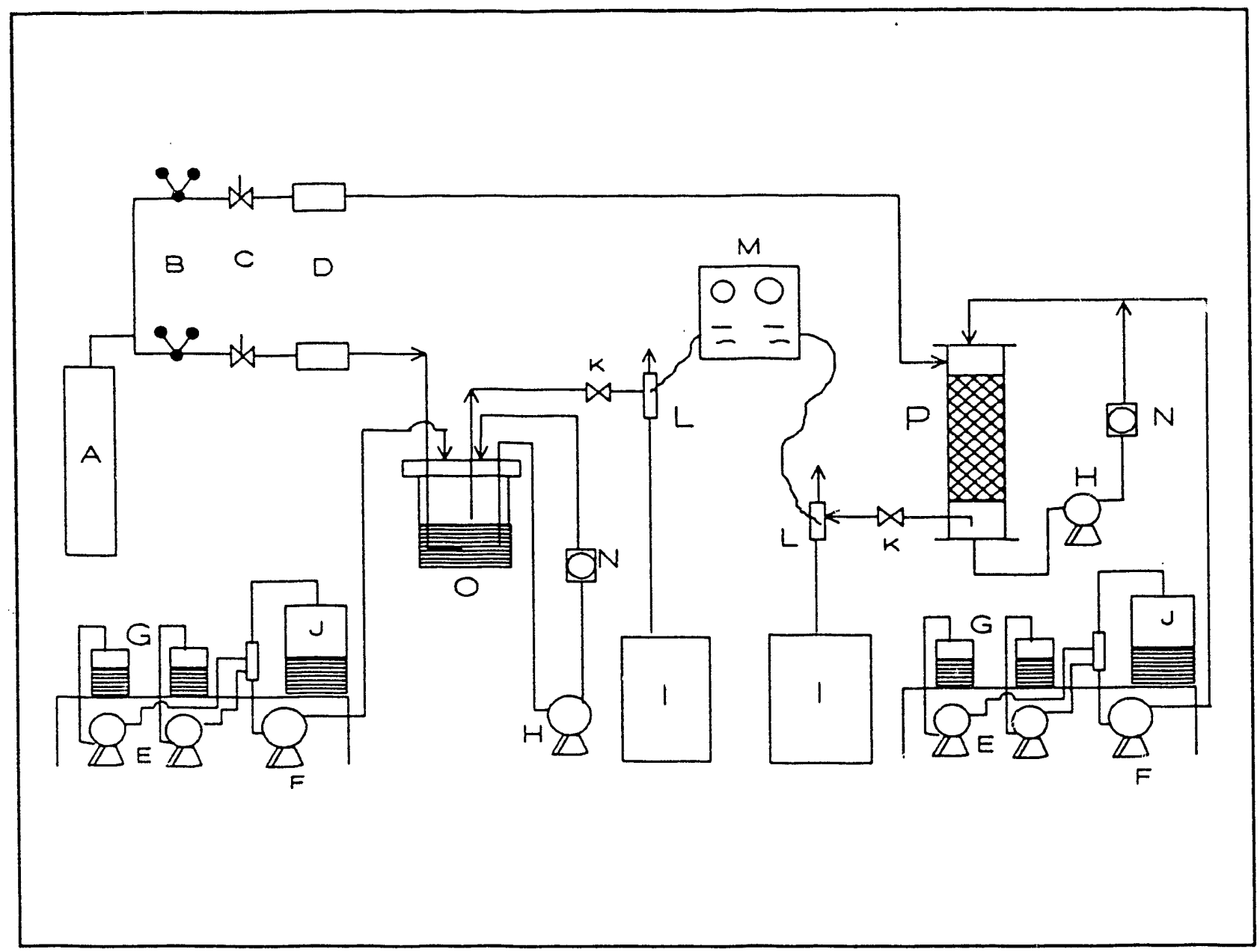

A. Feed Gas Bottle

B. Gas Regulators

C. Gas Shut-off Valves

D. Mass Flow Controller

E. Acid/Base Pumps

F. Reactor Feed Pumps

G. Acid/Base Storage Tanks

H. Recycles Pumps
I. Product storage Tanks

J. Reactor Feed Tanks

K. Pressure Cuntrol Valves

L. pH Measuring Port \& Gas-Liquid Separator

M. pH Controller

N. Sight Glass

O. CSTR

P. Column Reactor

Figure 1: Hi-pressure Reaction system 


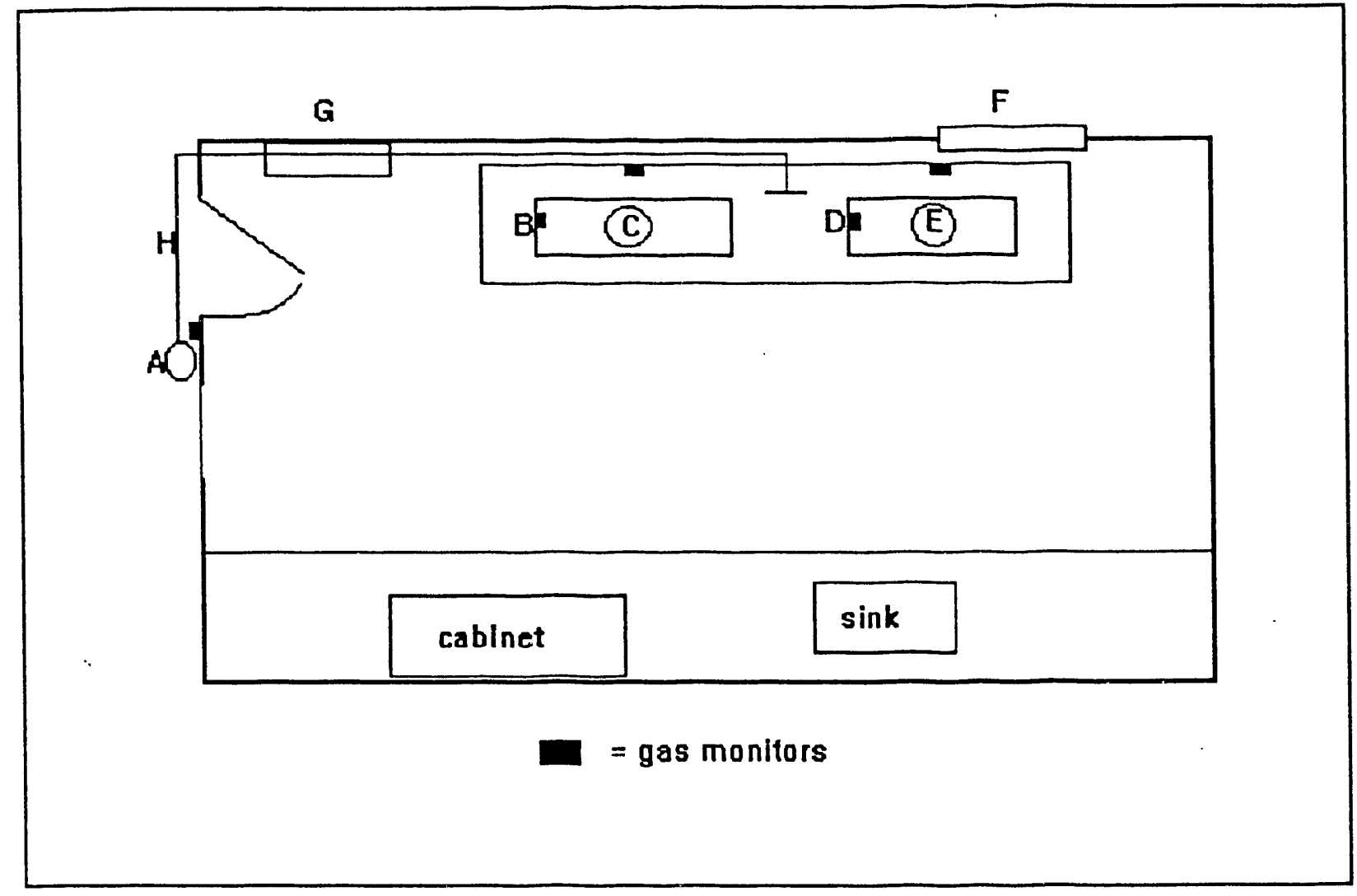

A. Gas Feed Bottle

B. Pump Box for CSTR

C. CSTR

D. Pump Box for Column Reactor

E. Column Reactor

F. Exhaust Fan

G. Room Heater

H. Gas Feed Line

Figure 2: Room Diagram 

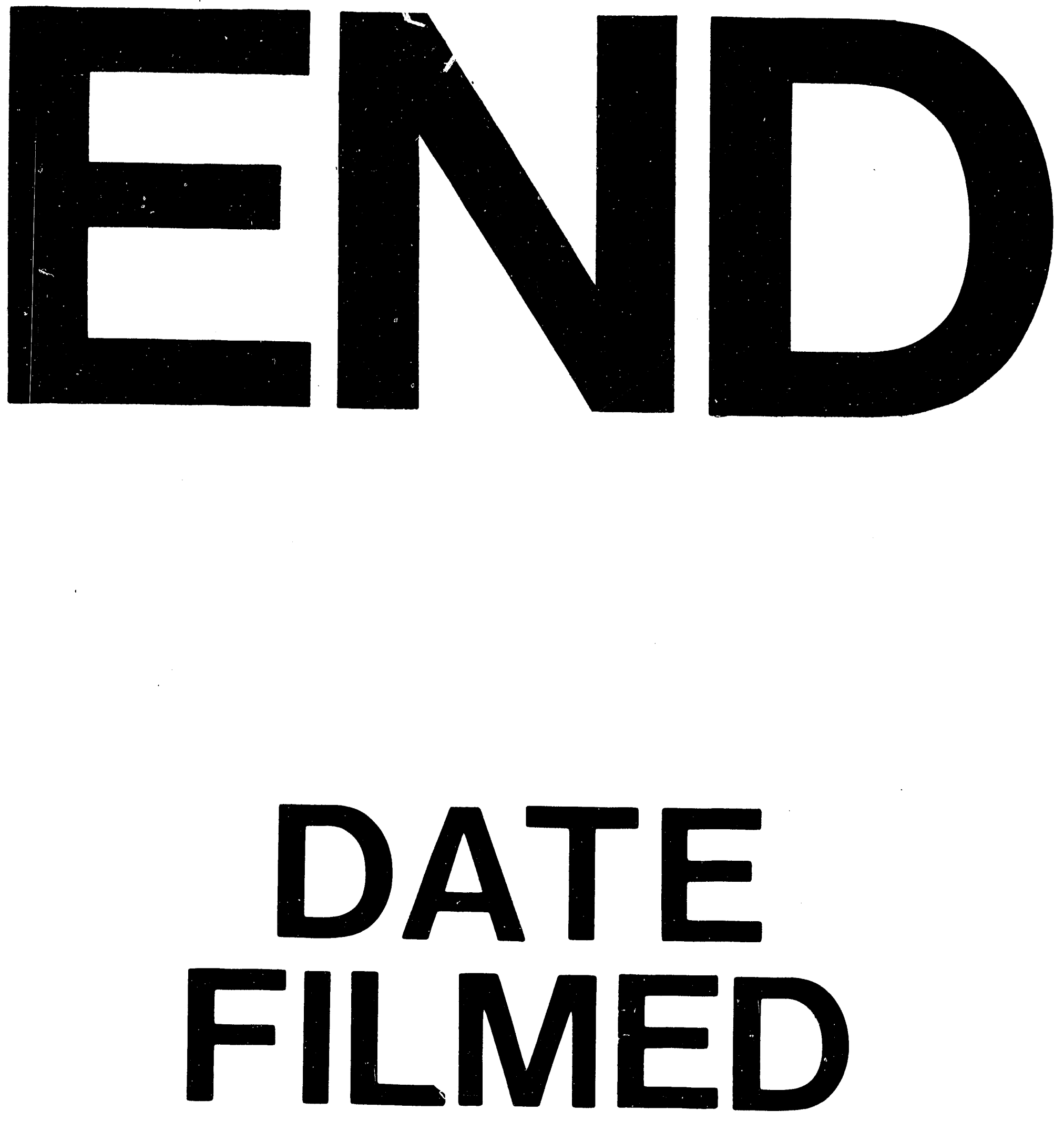

.

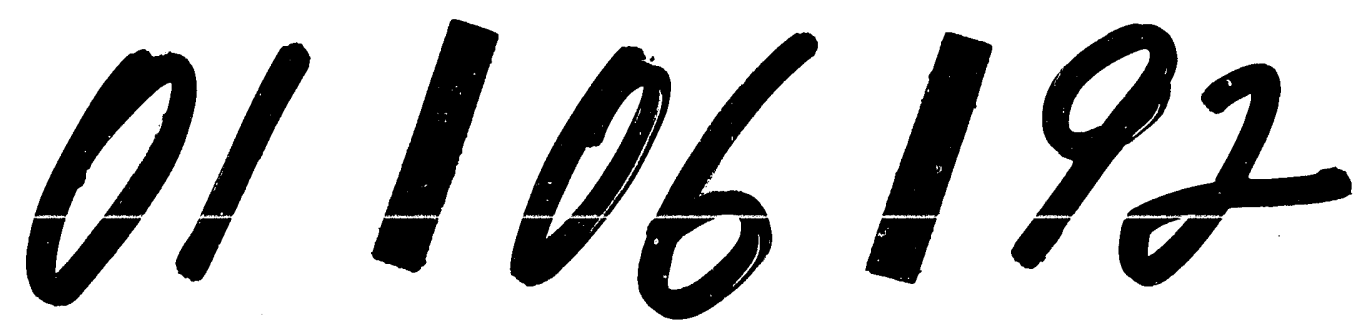


